\title{
POLLEN CONCENTRATIONS OF SOME PLANTS IN THE AIR OVER OLSZANICA (BIESZCZADY NISKIE MOUNTAINS) AND WROCŁAW IN THE 2008 SEASON
}

\author{
Małgorzata Malkiewicz, Kamilla Klaczak
}

\author{
Department of Paleobotany, Institute of Geological Sciences, Wrocław University, 50-205 Wrocław, Cybulskiego 34, Poland \\ e-mail: malgorzata.malkiewicz@ing.uni.wroc.pl
}

Received: 7.09.2010

\section{Abstract}

This paper presents the results of an analysis of pollen season patterns for taxa which show the strongest allergenic activity (alder, birch, grasses, and mugwort) in 2008 in the air over Wrocław and Olszanica. The study was carried out using the volumetric method (Burkard trap). The results show variation in pollen seasons between the analyzed localities. An attempt was made to find out in which of the sites in question - the urban site or the rural one - there was a greater risk of allergens of the selected plants.

The results of the present study show that the alder, birch and grass pollen seasons in 2008 started and ended earlier in Wrocław, and maximum pollen concentrations were definitely lower. But the mugwort pollen season started earlier and ended much later in Olszanica, while maximum pollen concentration of this taxon was more than twice lower than in Wrocław. In 2008 in the investigated localities, the highest pollen concentrations of the plants in question occurred in the following months: alder in February, birch in April, grasses in June, while mugwort in August. In 2008 alder and birch pollen allergen risk was comparable in the investigated urban and rural environment. However, grass and mugwort pollen allergens posed a significantly greater threat in the rural environment than in Wrocław.

Key words: aeroalergens, Burkard trap, pollen seasons, Alnus, Betula, Poaceae, Artemisia, Wrocław, Olszanica, Bieszczady Mountains

\section{INTRODUCTION}

In the last years, pollen production by plants has been studied in detail because of the increasing incidence of pollinosis. This disease is primarily caused by pollen allergens of anemophilous plants ( $\mathrm{Ne} \mathrm{g} r$ i $\mathrm{n} \mathrm{i}$, 1992). In northern and central Europe, pollen of alder (Alnus sp.) and birch (Betula sp.) has the strongest allergenic properties among trees, while among herba- ceous plants pollen of grass (Poaceae) and mugwort (Artemisia sp.) (W hil et al. 1998). These taxa are the most frequent cause of seasonal rhinoconjunctivitis in our climatic zone (R a p i e j k o et al. 2007).

In the moderate climate, anemophilous plants show a characteristic pattern of pollen production associated with the seasons of the year. Pollen of alder ( $A l$ nus sp.) appears earliest in the air, as early as the turn of winter and spring. On sunny days, its concentration may exceed even 2000 grains $\times 1 \mathrm{~m}^{3}$ of air (W e r y s z k o-Ch mi e lew s k a et al. 2001), whereas the first disease symptoms in people allergic to alder pollen appear with exposition to a concentration of 45 grains $\times 1 \mathrm{~m}^{3}$ of air (R a p i e j k o , 2007). In the spring period, pollen of birch (Betula sp.) is a strong aeroallergen. Its concentration in Poland reaches a very high level, and the number of days with a concentration exceeding the threshold values is usually more than 10-15 (W e rys zko-Chmie lew ska et al. 2001; R api e j k o et al. 2007.) During the late summer period, allergens of mugwort (Artemisia sp.) are responsible for most of pollinosis symptoms. In Poland the highest concentration of mugwort pollen has been recorded most frequently in the first half of August ( $\mathrm{S} \mathrm{t} \mathrm{a} \mathrm{c} \mathrm{h}$, 1996; C hło pek and Dąbrow ska, 2006; M a l$\mathrm{k}$ i e w i c z, 2006a, 2006b). The first disease symptoms in people with hypersensitivity to pollen allergens of this taxon occur at a concentration of 30 grains $\times 1 \mathrm{~m}^{-3}$ of air, while at a concentration of 70 grains $\times 1 \mathrm{~m}^{-3}$ of air acute clinical symptoms are observed ( $\mathrm{R}$ a p i e j k o et al. 2004, 2007; W e r y s z k o- C h mi e le w s k a et al. 2005). Grasses (Poaceae) have the longest pollen production season - from May to the end of September. In Poland the main pollen shed period occurs in the second half of May, in June and July, and during this period these are allergens of this species-rich 
family which are the main cause of pollen allergy (Ligęziński and Rapiejko, 1994). During the grass flowering period, more than $90 \%$ of sufferers allergic to grass pollen suffer from allergic complaints (O b tu fowicz et al. 1991). Disease symptoms in people with hypersensitivity to pollen allergens of this taxon occur at a concentration of 50 grains $\times 1 \mathrm{~m}^{-3}$ of air (R a p i e j k o et al. 2007; R a pi e j k o, 2008).

This paper presents the results of an analysis of pollen season patterns for taxa which show the strongest allergenic activity (alder, birch, grasses, and mugwort) in 2008 in the air over Wrocław and Olszanica. In analysing the results, special attention was paid to variations in pollen concentrations during the growing season as well as to differences in pollen season duration and patterns in the investigated localities. An attempt was made to find out in which of the sites in question - the urban site or the rural one - there was a greater risk of allergens of the selected plants.

\section{MATERIALS AND METHODS}

The present study was conducted in 2008 in two localities - Wrocław and Olszanica (Bieszczady Niskie Mountains). Wrocław is located in south-western Poland, at the foreland of the Sudety Mountains, in the centre of the Silesian Lowland (Kondracki , 2001). This city is strongly affected by the oceanic climate. Winters are mild and short here, while the spring is early. The growing season lasts 225 days (K o s i b a , 1948; D u b i c k i et al. 2002). Olszanica is located in southeastern Poland, in Bieszczady Niskie Mts., in the western part of Eastern Carpathians. The mountain climate prevails in this area, mostly formed by atmospheric circulation (N o w o s a d, 1995). The growing season lasts 165 days (W in n i ki and Ze manek, 1998) (Fig. 1).

The investigations were carried out using the volumetric method (Burkard trap). In Wrocław the Burkard trap was placed in the city centre, on the roof of the Institute of Geological Sciences of the University of Wrocław, at a height of about $30 \mathrm{~m}$ above ground level. In the immediate vicinity of the sampling site, there are a dense urban built-up area and scanty patches of greenery. From the south, the building is surrounded by an alley of planes, while several horse-chestnut trees and small birches grow to the north of the building. In Olszanica the sampling site is about $9 \mathrm{~m}$ above ground level, on the roof of a single-family house. Nearby, there are low rural buildings, a crop field, and a mixed forest.

The 95\% method was used to determine the start and end dates of the pollen season. The start and end date, duration, annual pollen count, and maximum daily concentration were used to characterize pollen seasons for the selected taxa.

\section{RESULTS}

In the early spring period, alder pollen is the greatest threat to allergic people. In 2008 the alder pollen season started earlier in Wrocław - on 25 January. In Olszanica the pollen season began as late as 9 February and lasted one week longer, until 22 March (Table 1). Peak pollen shed occurred in both localities in the second half of February and almost at the same time. Maximum alder pollen concentration in Wrocław occurred on 24 February and it was 484 grains $\times 1 \mathrm{~m}^{-3}$ of air, whereas in Olszanica on 26 February and it was 604 grains $\times 1 \mathrm{~m}^{-3}$ of air (Fig. 2). The alder pollen season in Wrocław was shorter by 6 days, but the annual Alnus pollen count was higher by nearly 1300 grains (Table $1)$. The risk of alder pollen allergens in both localities in question was comparable, because the number of days with a concentration of more than 80 grains $\times 1 \mathrm{~m}^{3}$ of air was 22 .

Birch pollen belongs to the strongest aeroallergens of the spring period. In 2008 the pollen season of this taxon in both investigated localities started in the first half of April and lasted until the beginning of May. It began earlier in Wrocław (9 April) and lasted until 5 May (Table 1). In Olszanica the pollen season started on 12 April and was by 5 days shorter. Peak birch pollen shed occurred in both localities in the second half of April - in Wrocław on 21 April, while in Olszanica only 2 days later (23 April). Maximum Betula pollen concentration was higher in Olszanica and it was 2097 grains $\times 1 \mathrm{~m}^{3}$ of air, while in Wrocław the peak concentration reached only $75 \%$ of this value (Fig. 2). The annual birch pollen count was by far higher in Olszanica, in spite of the fact that the pollen season in this village was 5 days shorter. Despite a lower annual birch pollen count in Wrocław, the risk of allergens of this taxon was slightly higher. A concentration of more than 75 grains $\times 1 \mathrm{~m}^{3}$ of air, at which allergy symptoms appear in all people allergic to birch pollen, occurred on 21 days, whereas in Olszanica on 19 days.

The spring and summer period is a time of pollen production in different grass species from the large family of Poaceae. In 2008 the grass pollen season in Wrocław started quicker (10 May) than in Olszanica (1 June) and it was much longer. It lasted 84 days, whereas in Olszanica only 72 days (Table 1). Peak grass pollen shed in both localities occurred in the first half of June - in Wrocław on 4 June, and in Olszanica on 11 June (Fig. 2). Maximum pollen concentration was 3 times higher in Olszanica (334 grains $\times 1 \mathrm{~m}^{3}$ of air) than in Wrocław. The annual grass pollen count in Olszanica was 4240 grains, whereas in Wrocław 2695 grains. The number of days with a concentration of more than 50 grains $\times 1 \mathrm{~m}^{3}$ of air, at which disease symptoms appear in all people allergic to grass pollen 


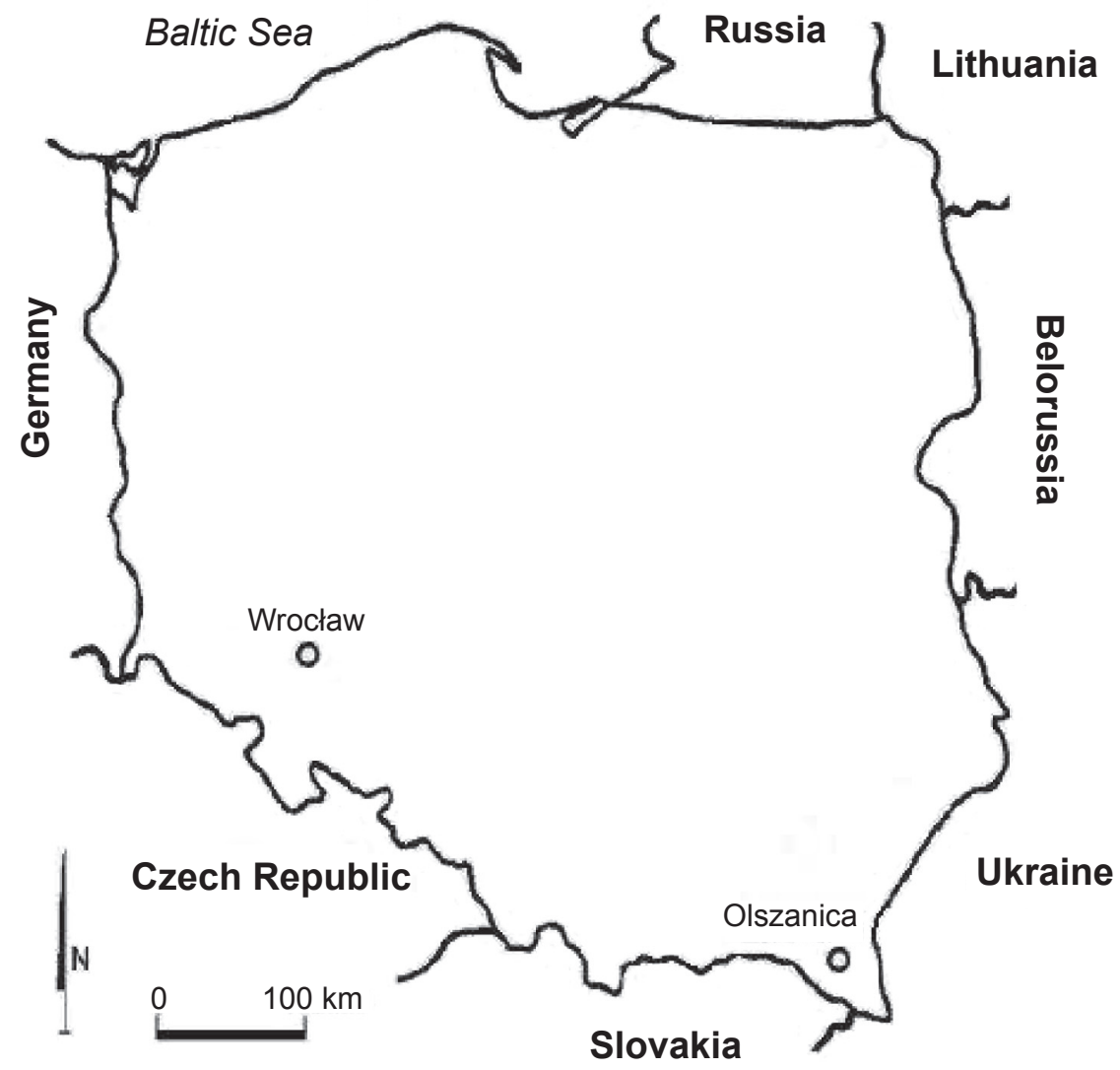

Fig. 1. Location of Wrocław and Olszanica

Table 1

Characteristics of Alnus, Corylus, Poaceae and Artemisia pollen seasons in Wrocław and Olszanica in 2008

\begin{tabular}{|c|c|c|c|c|c|c|c|}
\hline \multirow[b]{2}{*}{ Location } & \multirow[b]{2}{*}{ Taxa } & \multicolumn{3}{|c|}{ Pollen season } & \multirow{2}{*}{$\begin{array}{c}\text { Maximum } \\
\text { concentration } \\
(\mathrm{g} / \mathrm{m} 3)\end{array}$} & \multirow{2}{*}{$\begin{array}{c}\text { Date of } \\
\text { maximum } \\
\text { concentration }\end{array}$} & \multirow{2}{*}{$\begin{array}{l}\text { Annual } \\
\text { pollen } \\
\text { count }\end{array}$} \\
\hline & & Start & End & $\begin{array}{c}\text { Duration } \\
\text { (days) }\end{array}$ & & & \\
\hline \multirow{4}{*}{ Wrocław } & Alnus & 25-01 & $01-03$ & 37 & 484 & $24-02$ & 5988 \\
\hline & Betula & $09-04$ & $05-05$ & 27 & 1452 & $21-04$ & 10194 \\
\hline & Poaceae & $10-05$ & $01-08$ & 84 & 121 & $04-06$ & 2695 \\
\hline & Artemisia & $26-07$ & $21-08$ & 27 & 223 & $11-08$ & 1507 \\
\hline \multirow{4}{*}{ Olszanica } & Alnus & 09-02 & $22-03$ & 43 & 604 & $26-02$ & 4690 \\
\hline & Betula & $12-04$ & 03-05 & 22 & 2097 & 23-04 & 13742 \\
\hline & Poaceae & $01-06$ & $11-08$ & 72 & 334 & $11-06$ & 4240 \\
\hline & Artemisia & 22-07 & 27-09 & 68 & 86 & $11-08$ & 724 \\
\hline
\end{tabular}



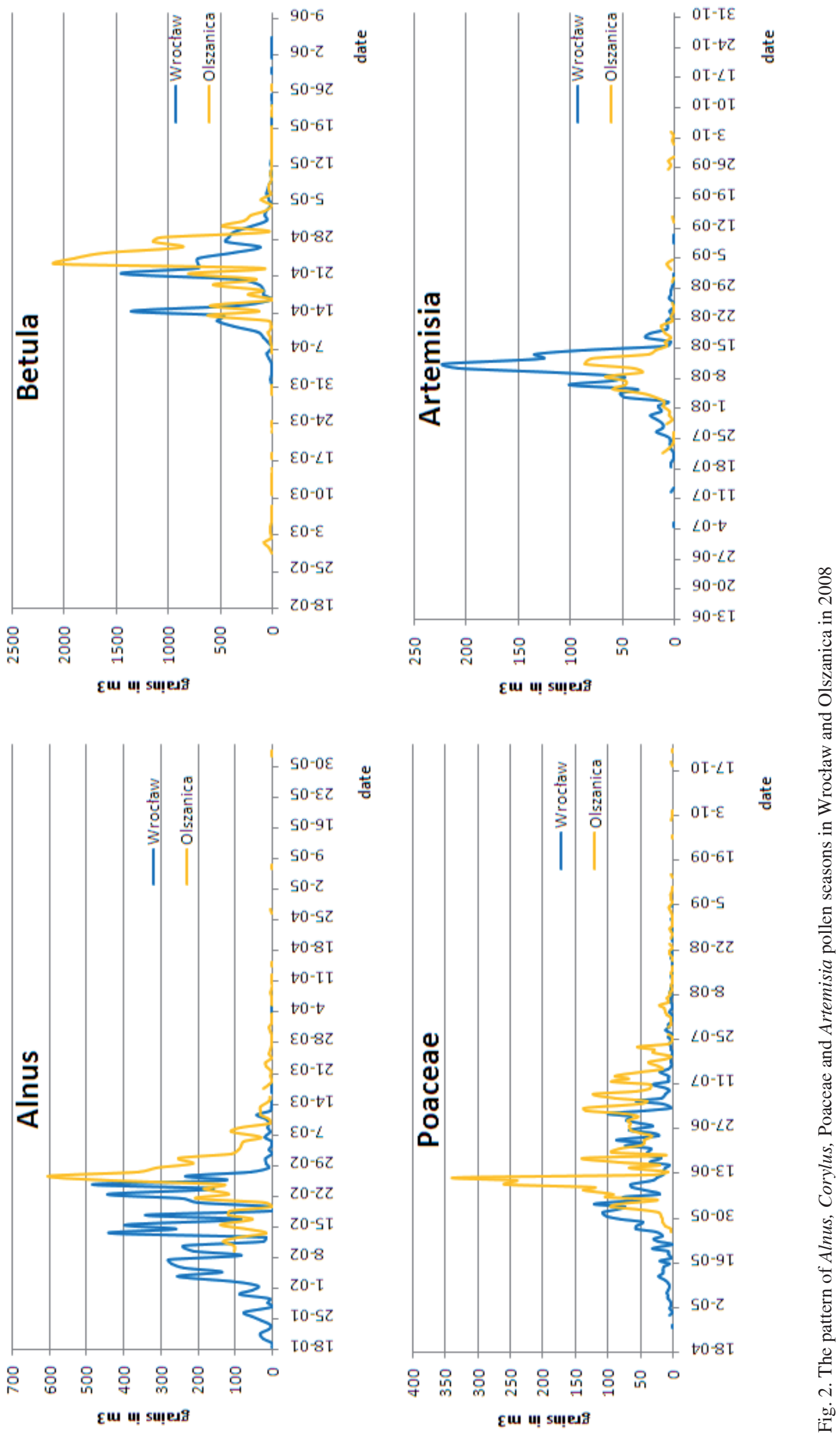
allergens, was much higher in Olszanica (33 days) than in Wrocław (20 days).

During the later summer period, mugwort pollen is a serious aeroallergen. In 2008 the pollen season of this taxon began in both localities in the third decade of July, but in Olszanica it lasted definitely longer. There, it ended as late as 27 September, whereas in Wrocław already on 21 August (Table 1). Peak pollen shed in both localities occurred on 11 August, but in Wrocław it was several times higher -223 grains $\times 1 \mathrm{~m}^{-3}$ of air - than in Olszanica (86 grains $\times 1 \mathrm{~m}^{-3}$ of air) (Fig. 2). The annual mugwort pollen count was more than two times larger in Wrocław. The risk of mugwort pollen allergens was different in both localities. The number of days with a concentration of more than 30 grains $\times$ $1 \mathrm{~m}^{-3}$ of air, at which the first disease symptoms appear, was 9 days in Olszanica and 12 in Wrocław.

\section{DISCUSSION}

The results of the present study show that the alder, birch and grass pollen seasons in 2008 started and ended earlier in Wrocław, and maximum pollen concentrations were definitely lower than in Olszanica. But the mugwort pollen season started earlier and ended much later in Olszanica, while maximum pollen concentration of this taxon was more than twice lower than in Wrocław.

The largest variations in pollen-season start dates were found in the case of alder and grasses. The alder pollen season in Wrocław started more than two weeks earlier than in Olszanica. Similar differences in the start date of pollen shed in 2008 were recorded between Sosnowiec and Lublin as well as between Szczecin and Warsaw (C hło pek et al. 2008b). The flowering of alder during a period of variable weather conditions and significant temperature fluctuations results in the start date of the pollen season and the intensity of pollen production being dependent on air temperature in winter and early spring ( $\mathrm{g}$ le sias et al. 2003). As a result of variable weather conditions in the first quarter of a year, start dates of the pollen season in Poland may also differ significantly in successive years (Weryszko-Chmielewska et al. 2001). In 2008 the alder pollen season in the investigated localities started relatively early, already in January and at the beginning of February, likewise in other cities of Poland in 2008 (C h lo p e k et al. 2008b). But both in the earlier years and in 2009, the alder pollen season started much later - at the end of February, and even in March (P u c et al. 2006, 2009; M a lki e w i c z et al. 2007). Such large differences in the start dates of the alder pollen season may result from the geographic location of the investigated localities and a stronger effect of the oceanic climate in western Poland.
The grass pollen season in 2008 began in Wrocław as many as 22 days faster than in Olszanica. Similar start dates of the grass pollen season were also found in other cities of western Poland (R a p i e j k o et al. 2008b). But in the cities of central and eastern Poland, these dates were similar to the start date of the pollen season in Olszanica. The accelerated start of the grass pollen season in Wrocław and in other cities of western Poland is probably a consequence of the interaction of a milder climate in this part of Poland and a specific urban agglomeration microclimate - the effect of the so-called "urban heat island" (D u b i c k i et al. 2002).

The present study also demonstrated significant differences in the concentration dynamics of alder, birch, grass, and mugwort pollen in the localities in question. In spite of sometimes large differences in pollen season duration and maximum concentrations, the peak days of pollen shed for each of the taxon in question were close to each other. In the case of mugwort, the maximum concentration occurred in Wrocław and Olszanica exactly on the same day. However, in the case of alder, birch, and grasses, there was a time difference of 2 to 6 days in the dates of peak pollen release between the respective localities. The dates of maximum concentrations in 2008 in Wrocław and in Olszanica did not differ from the dates of peak pollen shed in other cities of Poland ( $\mathrm{R} \mathrm{a} \mathrm{p} \mathrm{i} \mathrm{j} \mathrm{k} \mathrm{o} \mathrm{et} \mathrm{al.}$ 2008a, 2008b; C h ł o p e k et al. 2008a, 2008b).

In 2008 in the investigated localities, the highest pollen concentrations of the plants in question occurred in the following months: alder in February, birch in April, grasses in June, while mugwort in August. Similar observations were made in other cities of Poland in the year in question (R a pi e j ko et al. 2008a, 2008b; C h ł o p e k et al. 2008a, 2008b). There were years in which high concentration values for these taxa appeared in other months. Most frequently, alder reaches the highest concentrations of its pollen in March (My szkow ska, 2006; Malki ewicz, 2006b; Puc, 2006). High values for birch pollen were sometimes recorded in May (S z c z e panek, 1994; Myszkowska, 2006; Chłopek and D ąbrowska, 2006). However, the highest grass and mugwort pollen concentrations were found in July (M y s z k ow s k a , 2006; S t a c h, 2006; P u c, 2006; Weryszko-Chmielewska and Piotrowska, 2006).

As a result of the present study it was found that in 2008 alder and birch pollen allergen risk was comparable in the investigated urban and rural environment. However, grass pollen allergens posed a significantly greater threat in the rural environment in Olszanica. The difference in the number of days with a concentration of more than 50 grains $\times 1 \mathrm{~m}^{-3}$ of air, at which 
disease symptoms appear in all people allergic to grass pollen (R a p i e j k o et al. 2007; R a p i e j k o, 2008), was as many as 13 days. Mugwort pollen allergen risk was significantly higher in Wrocław.

\section{REFERENCES}

Chłopek K., Dąbrowska K., 2006. Pyłek wybranych taksonów roślin w powietrzu Sosnowca w latach 20012005. [In:] E. Weryszko-Chmielewska (ed), Pyłek w aeroplanktonie różnych miast Polski. Lublin: 59-70 (in Polish)

Chłopek K., Piotrowska K., WeryszkoChmielewska E., Dąbrowska-Zapart K., Puc M. Malkiewicz M., Lipiec A., Winnicka I., Kalinowska E., Rapiejko P., ZielnikJ u rk i e w i c z B., 2008a. Analiza stężenia pyłku bylicy w wybranych miastach Polski w 2008 r. / The analysis of mugwort pollen counts in selected Polish cities in 2008. Alergoprofil, 4 (4): 35-39 (in Polish).

Chłopek K., Puc M. Malkiewicz M., Świebocka E., Modrzyński M., Ra piejko P.,Piotrowska K., Weryszko-Chmielewska E., Myszkowska D., D ą b r o w s k a -Z a p a r t K., 2008b. Analiza stężenia pyłku olszy w wybranych miastach Polski w 2008 r. / The analysis of alder pollen counts in selected Polish cities in 2008. Alergoprofil, 4 (2): 37-41 (in Polish).

Dubicki A., Dubicka M., Szymanowski M., 2002. Klimat Wrocławia. [In:] K. Smolnicki, M. Szykasiuk (eds), Środowisko Wrocławia. Informator 2002. Dolnośląska Fundacja Ekorozwoju, Wrocław: 9-25 (in Polish).

Iglesias I., Mendez J., Comtois P., 2003. Aerobiological survey of Alnus pollen in Ourense (N.W. Iberian Peninsula), 1999-2000. Grana, 42: 112-120.

Kondra cki J., 2001. Geografia regionalna Polski. Państwowe Wydawnictwo Naukowe, Warszawa (in Polish).

Ko sib a A., 1948. Klimat Ziem Śląskich. Wyd. Inst. Śląsk., Wrocław-Katowice (in Polish).

Ligęziński A., Rapiejko P., 1994. Koncentracja pyłku roślin w atmosferze Polski. / Plant pollen concentrations in the atmosphere of Poland. Pneumonol. Alergol. Pol. 62: 347-351 (in Polish).

Malkiewicz M., 2006a. Pyłek bylicy (Artemisia L.), pokrzywy (Urtica L.) i babki (Plantago L.) w powietrzu Wrocławia a latach 2002-2004. / Mugwort (Artemisia L.), nettle (Urtica L.), and plantain (Plantago L.) pollen in the atmosphere of Wrocław in the years 2002-2004. Acta Agrobot. 59 (1): 347-354 (in Polish).

Malkiewicz M., 2006b. Pyłek wybranych taksonów roślin w powietrzu Wrocławia w latach 2003-2005. [In:] E. Weryszko-Chmielewska (ed), Pyłek w aeroplanktonie różnych miast Polski. Lublin: 71-79 (in Polish).

Malkiewicz M., Chłopek K., Myszkowska D., Weryszko-Chmielewska E., Piotrowska K., Rapiejko A., Lipiec A., Puc M., 2007. Analiza stężenia pyłku olszy w wybranych miastach Polski w 2007 r. / The analysis of alder pollen counts in selected Polish cities in 2007. Alergoprofil, 3 (2): 35-40 (in Polish).

Myszkowska D., 2006. Pyłek wybranych taksonów roślin w powietrzu Krakowa, 2001-2005. [In:] E. WeryszkoChmielewska (ed), Pyłek w aeroplanktonie różnych miast Polski. Lublin: 21-30 (in Polish).

Negrini A. C., 1992. Pollen as allergens. Aerobiologia, 8: 9-15.

Now o s ad M., 1995. Zarys klimatu Bieszczadzkiego Parku Narodowego i jego otuliny w świetle dotychczasowych badań. / An outline of the climate of the Bieszczady National Park and its buffer zone in the light of existing research. Roczniki Bieszczadzkie, 4: 163-183 (in Polish).

Obtułowicz K., Szczepanek K., Radwan J., Grzywacz M., Adamus K., Szczeklik A., 1991. Correlation between airborne pollen incidence, skin trick tests and serum immunoglobulin in allergic people in Cracow, Poland. Grana, 30: 136-141.

P u c M., 2006. Pyłek wybranych taksonów roślin w powietrzu Szczecina, 2001-2005. [In:] E. Weryszko-Chmielewska (ed), Pyłek w aeroplanktonie różnych miast Polski. Lublin: 49-57 (in Polish).

Puc M., Weryszko-Chmielewska E., Piotrowska K., Grinn-Gofroń A., Myszkowska D., Rapiejko P., Antonik P., Malkiewicz M., Puc M., 2006. Stężenie pyłku olszy w powietrzu wybranych miast Polski w $2006 \mathrm{r}$. / Alder pollen counts in the air of selected Polish cities in 2006. Alergoprofil, 2 (2): 37-42 (in Polish).

Puc M., Myszkowska D., Lipiec A., Rapiejko P., Weryszko-Chmielewska E., Piotrowska K., Malkiewicz M., Puc M., Zielnik-Jurkiewicz B., Myśliwy M., Grinn-Gofroń A., Wolski T., Winnicka I., Jurkiewicz D., 2009. Pyłek olszy w powietrzu wybranych miast Polski w 2009 r. / Alder pollen counts in the air of selected Polish cities in 2009. Alergoprofil, 5 (1): 49-53 (in Polish).

Rapiejko P., 2007. Alergeny pyłku olszy. / Alder pollen allergens. Alergoprofil, 3 (3): 28-33 (in Polish).

R a piejko P., 2008. Alergeny pyłku roślin. Medical Education, Warszawa (in Polish).

Rapiejko P., Lipiec A., Wojdas A., Jurkiewicz D., 2004. Threshold pollen concentration necessary to evoke allergic symptoms. Int. Rev. Allergol. Clin. 10 (3): 91-94.

Rapiejko P., Stankiewicz W., Szczygielski K., Jurkiewicz D., 2007. Progowe stężenie pyłku roślin niezbędne do wywołania objawów alergicznych. / Threshold plant pollen concentration necessary to evoke allergic symptoms. Otolaryngol. Pol. 61 (4): 591-594 (in Polish).

Rapiejko P., Puc M., Weryszko-Chmielewska E., Piotrowska K., Myszkowska D., Malkiewicz M., Chłopek K., Wojdas A., Lipiec A., Rapiejko A., Świebocka E., Puc M., Modrzyński M., Majkowska- 
Wojciechowska B., 2008a. Pyłek brzozy w wybranych miastach Polski w roku 2008. / Birch pollen in the selected Polish cities in 2008. Alergoprofil, 4 (2): 54-59 (in Polish).

Rapiejko P., Malkiewicz M., Chłopek K., Puc M., Zielnik-Jurkiewicz B., Winnicka I., Lipiec A., 2008b. Pyłek traw w powietrzu wybranych miast Polski w 2008 roku. / Grass pollen in the air of selected Polish cities in 2008. Alergoprofil, 4 (4): 40-44 (in Polish).

St a ch A., 1996. Pollen fall of certain allergenic plants in Poznań 1992-1995, Contribution to compilation of pollen calendar for Poznań and surrounding area. Ann. Agric. Environ. Med. 3: 99-108.

S t a ch A., 2006. Pyłek wybranych taksonów roślin w powietrzu Poznania, 2001-2005. [In:] E. Weryszko-Chmielewska (ed), Pyłek w aeroplanktonie różnych miast Polski. Lublin: 31-47 (in Polish).

S z c z e p a n ek K., 1994. Pollen calendar In Cracow (southern Poland), 1982-1991. Aerobiol. 10 (1): 65-70.

Weryszko-Chmielewska E., Piotrowska K., 2006. Pyłek wybranych taksonów roślin w powietrzu Lublina w latach 2001-2005. [In:] E. Weryszko-Chmielewska (ed), Pyłek w aeroplanktonie różnych miast Polski. Lublin: 105-115 (in Polish).

Weryszko-Chmielewska E., Puc M., Rapiejko P., 2001. Comparative analysis of pollen counts of Corylus, Alnus and Betula in Szczecin, Warsaw and Lublin (2000-2001). Ann. Agric. Environ. Med. 8: 235-240.

Wihl J. A., Ipsen B., Nuchel P. B., Munch E. P., Jann i che E. P., L oven ste in H., 1998. Immunotherapy with partially purified and standardized tree pollen extracts. J. Allergy Clin. Immunol. 98: 99-106.

Winnicki T., Zemanek B., 1998. Przyroda Bieszczadzkiego Parku Narodowego. Wydawnictwo Bieszczadzkiego Parku Narodowego, Ustrzyki Dolne (in Polish).

\section{Stężenie pyłku wybranych roślin w powietrzu Olszanicy (Bieszczady Niskie) i Wrocławia w sezonie 2008}

\section{Streszczenie}

$\mathrm{W}$ pracy przedstawiono wyniki analiz przebiegu sezonów pyłkowych taksonów o najsilniejszym działaniu alergogennym (olszy, brzozy, traw i bylicy) w roku 2008 w powietrzu Wrocławia i Olszanicy. Przy analizie wyników szczególną uwagę zwrócono na zmienność stężenia pyłku w sezonie wegetacyjnym oraz na różnice $\mathrm{w}$ długości i przebiegu sezonów pyłkowych w badanych miejscowościach. Podjęto próbę stwierdzenia, w którym $\mathrm{z}$ analizowanych stanowisk - miejskim czy wiejskim - jest większe zagrożenie alergenami wybranych roślin.

W wyniku przeprowadzonych badań wykazano, że sezony pyłkowe olszy, brzozy i traw w 2008 roku rozpoczęły się i zakończyły wcześniej we Wrocławiu, a maksymalne stężenia były zdecydowanie niższe. Natomiast sezon pyłkowy bylicy rozpoczął się wcześniej i zakończył znacznie później w Olszanicy, a maksymalne stężenie pyłku tego taksonu było ponad dwukrotnie niższe niż we Wrocławiu.

Przeprowadzone badania wykazały również duże różnice w dynamice stężenia pyłku olszy, brzozy, traw i bylicy w badanych miejscowościach. Pomimo niekiedy znacznych różnic w długości sezonów pyłkowych i w maksymalnych stężeniach, szczyty pylenia dla każdego analizowanego taksonu były do siebie zbliżone. W przypadku bylicy maksymalne stężenie pojawiło się we Wrocławiu i Olszanicy dokładnie w tym samym dniu. Natomiast w przypadku olszy, brzozy i traw szczyt pylenia rejestrowano we Wrocławiu wcześniej o 2 do 6 dni.

W 2008 roku zagrożenie alergenami pyłku brzozy i olszy było porównywalne w badanym środowisku miejskim i wiejskim. Natomiast alergeny pyłku traw stanowiły znacznie większe zagrożenie w środowisku wiejskim Olszanicy, a pyłku bylicy we Wrocławiu. 
